\title{
HTLV-1 Antibody Positive
}

National Cancer Institute

\section{Source}

National Cancer Institute. HTLV-1 Antibody Positive. NCI Thesaurus. Code C141313.

An indication that antibodies that recognize the human T-cell lymphotropic virus 1 have been detected in a sample. 